\title{
Bacterial flora in abnormalities of the female genital tract
}

\author{
A. M. GORDON, H. E. HUGHES, AND G. T. D. BARR \\ From Glasgow Royal Infirmary
}

SYNOPSIS The bacterial flora associated with certain common abnormalities of the female genital tract were studied. The abnormalities included were trichomonal infestation of the vagina, the epithelial inflammation and cellular atypia associated with protozoal infestation, and erosions of the cervix.

Trichomonas vaginalis infestation and marked epithelial inflammation were associated with a very varied bacterial flora in which Mycoplasma species, streptococci, and 'Haemophilus vaginalis' (Gardner and Dukes, 1955) were often prominent. No cases of vaginitis attributable to Haemophilus vaginalis were detected. An essentially normal bacterial flora accompanied erosions of the cervix.

This paper describes the results of an investigation of the bacterial flora accompanying inflammation of the female genital tract. The principal purpose of this study was to establish the microbial floral variations in the presence of Trichomonas vaginalis infestation, with special reference to the group of patients showing cytological evidence of the severe epithelial cellular reactions to be described elsewhere (Hughes, Gordon, and Barr, 1966). An investigation of the vaginal flora associated with cervical erosions was also included, and in view of their equivocal status as pathogens of the female genital tract, it was considered of particular interest to undertake special cultural examinations for organisms of the Mycoplasma (P.P.L.O.) group, and for 'Haemophilus vaginalis' as described by Gardner and Dukes (1955).

\section{MATERIAL AND METHODS}

The clinical material utilized in this investigation, the methods of clinical assessment and classification of the patients, and the specimen collection procedures were as described elsewhere (Hughes et al., 1966).

PREPARATION, EXAMINATION, AND GRADING OF SMEARS Each cervical smear was air-dried, heat-fixed, and stained by Gram's method, using the modification of technique described by Preston and Morrell (1962). The Gramstained films were examined by light microscopy, under oil immersion, and were assigned to one of three morphological floral grades (I, II, or III) based upon the following criteria: Smears showing a morphological flora exclusively of Döderlein type, were assigned to grade I, smears showing a mixed morphological flora, but which included organisms morphologically resembling lactobacilli (Döderlein's bacilli) were classified as grade II ; a grade III smear was defined as one showing a mixed Received for publication 9 June 1966. bacterial flora, totally devoid of organisms morphologically resembling lactobacilli.

CULTURAL TECHNIQUES For the cultivation of the aerobic and anaerobic flora of the genital tract, freshly prepared moist plates of Casman's medium enriched with $10 \%$ defibrinated horse blood (Burroughs Wellcome) were inoculated, in duplicate, from each cervical swab specimen. To satisfy the microaerophilic and frankly anaerobic requirements of many of the constituents of the vaginal flora, one plate was incubated anaerobically in a McIntosh and Fildes jar, while the second plate was incubated under increased $\mathrm{CO}_{2}$ tension. All cultures were maintained at $37^{\circ} \mathrm{C}$. for 72 hours, after which the anaerobic and $\mathrm{CO}_{2}$ plates were examined in parallel, and the bacterial flora of the specimens fully elucidated by standard bacteriological methods. In particular, the identification of Haemophilus vaginalis was based upon the criteria set by Dukes and Gardner (1961).

The solid medium employed for the cultivation of organisms of the Mycoplasma (P.P.L.O.) group was essentially that of Chanock, Hayflick, and Barile (1962), comprising Difco P.P.L.O. agar, 7 parts, horse serum, 2 parts, and yeast extract, 1 part.

The P.P.L.O. agar base was prepared in 70-ml. aliquots, and sterilized by autoclaving. After cooling to $50^{\circ} \mathrm{C}$., the base medium was enriched with $20 \mathrm{ml}$. sterile (Seitz filtered) horse serum (Burroughs Wellcome no. 3) and $10 \mathrm{ml}$. of a freshly prepared $25 \%$ extract of baker's yeast. The medium was further supplemented with $20 \mu \mathrm{g} . / \mathrm{ml}$. of a sterile aqueous solution of D.N.A. (sodium salt of D.N.A. from calf thymus gland, B.D.H. Ltd.).

Penicillin in a concentration of 500 units per $\mathrm{ml}$., and thallium acetate in a final concentration of $1: 2,000$ were included as bacterial inhibitors and the medium was used at a final $p \mathrm{H}$ of $7 \cdot 9$. Following inoculation, plates were sealed with adhesive, and were incubated aerobically in a moist canister at $37^{\circ} \mathrm{C}$. for four days, after which they were examined in obliquely transmitted light, using a 
low-power objective, for 'fried-egg' colonies suggestive of mycoplasmas. A more precise morphological examination of such colonies was made by the agar-block fixation and Giemsa staining technique of Klieneberger-Nobel (1950). In order to avoid confusion with possible L-forms of bacteria, final identification of these organisms as mycoplasmas was dependent upon their successful and stable subculture on P.P.L.O. medium devoid of penicillin.

\section{RESULTS}

Table I summarizes the bacteriological findings in each of three clinical categories, 'trichomonal discharge', 'non-trichomonal discharge', and 'discharge absent', based on symptoms and on the clinical appearances of the vaginal discharge. Table II shows the variations of microbial flora in the presence of Trichomonas vaginalis infestation.

\section{TABLE I}

ANALYSIS OF MICROBIAL FLORA OF THE VAGINA IN EACH OF THREE CLINICAL CATEGORIES

Microbial Flora Clinical Category

\begin{tabular}{|c|c|c|c|}
\hline & \\
\hline & $\begin{array}{l}\text { Discharge } \\
\text { Absent } \\
(\%)\end{array}$ & $\begin{array}{l}\text { Non-trichomonal } \\
\text { Discharge } \\
(\%)\end{array}$ & $\begin{array}{l}\text { Trichomonal } \\
\text { Discharge } \\
(\%)\end{array}$ \\
\hline Grade I & $43 \cdot 0$ & $38 \cdot 1$ & $16 \cdot 2$ \\
\hline Grade II & $33 \cdot 4$ & $33 \cdot 1$ & $33 \cdot 8$ \\
\hline Grade III & $23 \cdot 6$ & $28 \cdot 8$ & $50 \cdot 0$ \\
\hline Mycoplasma species & $15 \cdot 3$ & $20 \cdot 0$ & $32 \cdot 6$ \\
\hline Haemophilus vaginalis & $9 \cdot 8$ & $12 \cdot 8$ & 28.0 \\
\hline Aerobic streptococci & $24 \cdot 2$ & $24 \cdot 7$ & $27 \cdot 7$ \\
\hline Lactobacilli & $81 \cdot 0$ & $72 \cdot 0$ & $52 \cdot 0$ \\
\hline Corynebacteria & $39 \cdot 0$ & $28 \cdot 9$ & $32 \cdot 8$ \\
\hline Candida species & 9.7 & $10 \cdot 2$ & 6.8 \\
\hline Acinetobacter species & 0.0 & $\mathbf{3 \cdot 0}$ & $1 \cdot 6$ \\
\hline Neisseria species & 0.0 & 0.8 & 0.0 \\
\hline Micrococci & $9 \cdot 4$ & $12 \cdot 1$ & $14 \cdot 3$ \\
\hline †Enterobacteria & $12 \cdot 2$ & $9 \cdot 0$ & $15 \cdot 6$ \\
\hline$\ddagger$ Anaerobic flora & $21 \cdot 0$ & 26.9 & $29 \cdot 3$ \\
\hline
\end{tabular}

*Includes staphylococcus and micrococcus.

†Includes Escherichia, Proteus-Providencia, Klebsiella-Aerobacter groups.

†Includes anaerobic streptococci, Veillonella, Bacteroides, Clostridium.

Specimens from the two negative clinical categories showed no significant difference in the distribution of floral gradings, nor in the frequency of occurrence of individual members of the vaginal bacterial flora. In particular, the incidence of P.P.L.O. and of Haemophilus vaginalis was very similar. The bacterial flora of specimens associated with clinically positive cases showed wide differences from the two preceding groups. The striking morphological differences were reflected in the cultural findings. Thus, lactobacilli were cultured from only $52 \%$ of these specimens, while the frequency of isolation of Haemophilus vaginalis $(28.0 \%)$, and of P.P.L.O. (32.6\%) was significantly higher than in the two non-trichomonal clinical categories.

When the microbial flora were considered in relation to the degree of protozoal infestation, marked
TABLE II

MICROBIAL FLORA ASSOCIATED WITH TRICHOMONAS VAGINALIS INFESTATION

\begin{tabular}{|c|c|c|c|}
\hline \multirow[t]{3}{*}{ Microbial Flora } & \multicolumn{3}{|c|}{ Papanicolaou Smear } \\
\hline & \multicolumn{3}{|c|}{ Trichomonas Vaginalis } \\
\hline & $\begin{array}{l}\text { Absent } \\
(\%)\end{array}$ & $\begin{array}{l}\text { Small } \\
\text { Numbers } \\
(\%)\end{array}$ & $\begin{array}{l}\text { Large } \\
\text { Numbers } \\
(\%)\end{array}$ \\
\hline Grade I & $57 \cdot 0$ & $32 \cdot 0$ & 6.4 \\
\hline Grade II & $26 \cdot 2$ & $41 \cdot 0$ & $29 \cdot 0$ \\
\hline Grade III & $16 \cdot 8$ & $27 \cdot 0$ & $64 \cdot 6$ \\
\hline Mycoplasma species & $10 \cdot 5$ & $30 \cdot 0$ & $59 \cdot 2$ \\
\hline Haemophilus vaginalis & $9 \cdot 8$ & $10 \cdot 9$ & $25 \cdot 8$ \\
\hline Aerobic streptococci & $12 \cdot 8$ & $23 \cdot 5$ & $64 \cdot 5$ \\
\hline Lactobacilli & $82 \cdot 0$ & $76 \cdot 0$ & $35 \cdot 0$ \\
\hline Corynebacteria & $37 \cdot 3$ & $32 \cdot 6$ & $31 \cdot 8$ \\
\hline Candida species & $9 \cdot 8$ & $12 \cdot 0$ & $3 \cdot 2$ \\
\hline Acinetobacter species & 0.0 & 1.8 & 7.0 \\
\hline Neisseria species & 0.0 & 0.9 & 0.0 \\
\hline Micrococci & $8 \cdot 1$ & $9 \cdot 0$ & $10 \cdot 7$ \\
\hline Enterobacteria & $8 \cdot 7$ & $10 \cdot 9$ & $25 \cdot 0$ \\
\hline Anaerobic flora & $21 \cdot 5$ & $26 \cdot 4$ & $40 \cdot 0$ \\
\hline
\end{tabular}

differences of incidence were noted. The frequency of grade I bacterial flora declined steeply from $57 \%$ in specimens devoid of protozoa to only $6.4 \%$ in specimens showing numerous protozoa. On culture, the most impressive variations of incidence were shown by the aerobic streptococci and the mycoplasmas. A good correlation was noted between the frequency of streptococci (predominantly nonhaemolytic strains) and increasing degrees of protozoal infestation, rising from $12.8 \%$ in specimens devoid of trichomonads, to $64.5 \%$ in heavily infested specimens. The incidence of mycoplasmas rose progressively from $10.5 \%$ in trichomonad-negative specimens to $59.0 \%$ in specimens containing many protozoa. Less striking differences were noted in the frequency of isolation of other micro-organisms. The incidence of Haemophilus vaginalis was higher $(25.8 \%)$ in heavily infested vaginal exudates than in uninfested exudates. The strictly anaerobic vaginal species and members of the Enterobacteriaceae were also present in an appreciably higher percentage of the Trichomonas vaginalis-infested specimens. Candida species were infrequently detected in heavily infested exudates.

A comparison of trichomonal infestation and of the microbial flora of specimens with cytological evidence of mild or moderate inflammation with that of specimens showing a severe inflammatory reaction (with or without nuclear atypia) is shown in Table III. A comparison of the two categories revealed significant differences in the distribution both of Trichomonas vaginalis and of bacterial floral grades.

On culture, a significantly higher incidence of mycoplasmas, non-haemolytic aerobic streptococci, and of Haemophilus vaginalis was found in the severe inflammatory group. The frequency of occurrence of 
TABLE III

MICROBIAL FLORA ASSOCIATED WITH VARYING DEGREES
OF VAGINAL EPITHELIAL INFLAMMATION

Microbial Flora

Papanicolaou Smear

\begin{tabular}{ll}
\hline $\begin{array}{l}\text { Mild or Moderate } \\
\text { Inflammation }\end{array}$ & $\begin{array}{l}\text { Severe Inflammation } \\
(\%)\end{array}$ \\
$(\%)$
\end{tabular}

Trichomonas vaginalis $95 \cdot 1$

Grade I

Grade II

Grade III

Mycoplasma species

Haemophilus vaginalis

Aerobic streptococci

Lactobacilli

Corynebacteria

Candida species

Acinetobacter species

Neisseria species

Micrococci

Enterobacteria

Anaerobic flora

$47 \cdot 8$
$43 \cdot 2$
$36 \cdot 5$
$20 \cdot 3$
$15 \cdot 5$
$10 \cdot 2$
$20 \cdot 3$
$80 \cdot 4$
$46 \cdot 7$
$9 \cdot 4$
$1 \cdot 0$
$0 \cdot 3$
$7 \cdot 1$
$12 \cdot 7$
$21 \cdot 6$

$9 \cdot 5$

$40 \cdot 3$

$50 \cdot 2$

$39 \cdot 1$

$32 \cdot 0$

$41 \cdot 0$ !

$49 \cdot 1$

$34 \cdot 3$

$4 \cdot 2$

6.4

0.0
$9 \cdot 6$

$19 \cdot 3$

$37 \cdot 5$

Candida albicans was low in both categories, but particularly insignificant $(4.2 \%)$ in the specimens showing severe inflammation.

The incidence of trichomonal infestation and the bacterial flora of eroded and non-eroded cervices is shown in Table IV. The distribution both of Trichomonas vaginalis and of the floral gradings was very similar in both groups. Although mycoplasmas and Haemophilus vaginalis were isolated from a higher percentage of eroded cervices than those not eroded, these differences are not statistically significant. No significant differences were observed between the two categories with respect to the remainder of the vaginal bacterial flora.

TABLE IV

MICROBIAL FLORA ASSOCIATED WITH EROSIONS OF THE CERVIX

\begin{tabular}{lcc} 
Microbial Flora & $\begin{array}{l}\text { Erosions } \\
+ \\
(\%)\end{array}$ & $\begin{array}{l}\text { Erosions } \\
(\%) \\
(\%)\end{array}$ \\
\hline Trichomonas vaginalis & $50 \cdot 3$ & $58 \cdot 0$ \\
Grade I & $32 \cdot 3$ & $38 \cdot 8$ \\
Grade II & $43 \cdot 4$ & $33 \cdot 5$ \\
Grade III & $24 \cdot 3$ & $27 \cdot 7$ \\
Mycoplasma species & $26 \cdot 2$ & $17 \cdot 7$ \\
Haemophilus vaginalis & $17 \cdot 2$ & $12 \cdot 5$ \\
Aerobic streptococci & $27 \cdot 3$ & $24 \cdot 0$ \\
Lactobacilli & $75 \cdot 7$ & $72 \cdot 3$ \\
Corynebacteria & $41 \cdot 3$ & $30 \cdot 9$ \\
Candida species & $7 \cdot 1$ & $10 \cdot 1$ \\
Acinetobacter species & $2 \cdot 9$ & $2 \cdot 1$ \\
Neisseria species & $0 \cdot 0$ & $0 \cdot 0$ \\
Micrococci & $10 \cdot 4$ & $12 \cdot 8$ \\
Enterobacteria & $7 \cdot 1$ & $11 \cdot 8$ \\
Anaerobic flora & $27 \cdot 1$ & $24 \cdot 3$
\end{tabular}

\section{DISCUSSION}

In this study, the varied nature of the vaginal bacterial flora in the presence of protozoal infestation and of severe vaginal epithelial inflammation is in good agreement with generally accepted views that the almost exclusively aciduric Döderlein flora of the healthy vagina is largely replaced by a mixed flora in the presence of vaginitis. The strikingly low incidence of grade I (Döderlein) flora in smears showing cytological evidence of severe inflammation was associated, on culture, with a much more varied aerobic and anaerobic flora. In particular, significantly higher incidences of mycoplasma, aerobic streptococci, and of Haemophilus vaginalis were seen in the severe inflammatory category, while obligatory anaerobic streptococci, bacteroides spp., and members of the Enterobacteriaceae were isolated more frequently in the presence of severe inflammation. A similar pattern of variation was observed if the frequency of occurrence of these micro-organisms was correlated with the degree of Trichomonas vaginalis infestation. It is, of course, well known that vaginal lactobacilli bear a more or less inverse relationship to the degree of trichomonal infestation of the vagina, and this is well illustrated by the results of the morphological floral gradings, only $6.4 \%$ of smears containing numerous trichomonads being classified as grade I. The most impressive variations were seen in the incidence of the mycoplasma group and of the aerobic streptococci. Fifty-nine per cent of heavily infested exudates yielded mycoplasmas, but only $10.5 \%$ of non-infested exudates yielded these organisms. The incidence of the aerobic streptococci in specimens containing large numbers of protozoa was approximately five times that observed in non-infested specimens.

It is tempting to attach some special significance to the association of these organisms with trichomonal infestation, and to suggest some contributory role in the production of severe inflammation, but it seems likely that their more frequent occurrence in these circumstances merely reflects a more favourable environment for their proliferation. It is well documented that the growth of mycoplasmas in the vagina is greatly favoured by a shift of vaginal $p \mathrm{H}$ from the normal acid range of 4.0 to 4.5 towards alkalinity (Freundt, 1958; Bercovici, Persky, Rozansky, and Razin, 1962), while streptococci and 'coliform' organisms grow well above $p \mathrm{H} 6$. Such conditions pertain in trichomonal infection, and, furthermore, tissue necrosis associated with the inflammatory reaction favours the growth of most of these bacteria, especially the microaerophilic and anaerobic species. It is probable, therefore, that the presence of these organisms, normally commensals of the female genital tract, is entirely secondary to the protozoal infestation. Notwithstanding, the mycoplasma group and Haemophilus vaginalis merit special discussion in view of the conflicting views expressed regarding their pathogenic role in genital tract pathology. 
Although the first isolation of a P.P.L.O. from the human genito-urinary tract was from a Bartholin's abscess (Dienes and Edsall, 1937), it is still not clear whether these organisms play a significant pathogenic role in genito-urinary diseases. An extensive and often conflicting literature has developed during the last 20 years, and the subject has been widely reviewed by Edward (1954), Klieneberger-Nobel (1962), and recently by Hayflick and Chanock (1965). Occasionally P.P.L.O. have been found in abundance in inflammatory and pyogenic lesions of the genital tract. Among these have been Bartholin's gland abscesses, pelvic abscesses associated with puerperal infection or with salpingitis (Dienes, Ropes, Smith, Madoff, and Bauer, 1948), and tuboovarian abscesses (Randall, Stein, and Ayres, 1950). Slingerland and Morgan (1952) isolated P.P.L.O. from the blood and cervix of a woman with a postpartum febrile illness, and Stokes (1955) has reported a similar case of puerperal sepsis. Certainly, the increased frequency of P.P.L.O. in association with inflammatory diseases of the genital tract, especially trichomonal and gonococcal infections, is well documented (Randall et al., 1950; Freundt, 1953; Nicol and Edward, 1953; Somerson, Rubin, Smith, and Morton, 1955; Klieneberger-Nobel, 1959; Bercovici et al., 1962), the incidence often reaching $70 \%$ or $80 \%$ in these circumstances. These findings have been amply confirmed in the present investigation, almost $60 \%$ of the heavily infested exudates yielding a mycoplasma species.

The evidence regarding the pathogenicity of the small Gram-negative bacillus designated 'Haemophilus vaginalis' by Gardner and Dukes (1955) is equally conflicting. Furthermore, the taxonomic status of this organism is very doubtful. Thus Zinnemann and Turner (1963) have proposed that this organism more properly belongs to the genus Corynebacterium, although Amies and Garabedian (1963) believe that Haemophilus vaginalis is a dissociated form of certain lactobacillus strains. Several authors, notably Gardner and Dukes (1955, 1959), and Gardner, Dampeer, and Dukes (1957), Ray and Maughan (1956), and Brewer, Halpern, and Thomas (1957), have contended that this organism is the principal aetiological agent in cases of 'non-specific' bacterial vaginitis. Edmunds (1959) found an association between Haemophilus vaginalis and the presence of leucorrhoea or of a post-partum pyrexia, and suggested that this was the principal organism concerned in cases of so-called 'mixed bacterial' infections of the vagina. In contrast, several other authors (Heltai and Taleghany, 1959; Frampton and Lee, 1964; Robinson and Mirchandani, 1965) have not found any definite association between Haemophilus vaginalis and lower genital tract pathology.
Although, in the present investigation, Haemophilus vaginalis was more frequently observed in the presence of Trichomonas vaginalis infestation, a low incidence of the organism was found in the clinically non-trichomonal categories, and in no case was the organism present as a predominant constituent of the vaginal flora. Thus, no evidence was obtained that Haemophilus vaginalis itself was responsible for the non-trichomonal vaginal discharges.

With regard to cervical erosions, no significant differences in the distribution of bacterial flora of specimens from eroded and non-eroded cervices was found, though it is of interest to note the slightly higher incidence of mycoplasmas in the eroded group. This difference is not, however, statistically significant. These essentially normal bacteriological findings are quite consistent with the view that erosions of the cervix per se are not associated with gross disturbances of vaginal $p \mathrm{H}$ nor with marked inflammation in the vagina.

We wish to thank Miss F. M. Clouston for technical assistance.

\section{REFERENCES}

Amies, C. R., and Garabedian, M. (1963). Canad. J. publ. Hlth, 54, 50.

Bercovici, B., Persky, S., Rozansky, R., and Razin, S. (1962). Amer. J. Obstet. Gynec., 84, 687.

Brewer, J. I., Halpern, B., and Thomas, G. (1957). Ibid., 74, 834.

Chanock, R. M., Hayflick, L., and Barile, M. F. (1962). Proc. nat., Acad. Sci. (Wash.), 48, 41.

Dienes, L., and Edsall, G. (1937). Proc. Soc. exp. Biol. (N.Y.), 36, 740.

-, Ropes, M. W., Smith, W. E., Madoff, S., and Bauer, W. (1948). New Engl. J. Med., 238, 509.

Dukes, C. D., and Gardner, H. L. (1961). J. Bact., 81, 277.

Edmunds, P. N. (1959). J. Obstet. Gynaec. Brit. Emp., 66, 917.

Edward, D. G. (1954). J. gen. Microbiol., 10, 27.

Frampton, J., and Lee, Y. (1964). J. Obstet. Gynaec. Brit. Cwlth, 71, 436.

Freundt, E. A. (1953). Acta path. microbiol. scand., 32, 468.

(1958). The Mycoplasmataceae. Munksgaard, Copenhagen.

Gardner, H. L., and Dukes, C. D. (1955). Amer. J. Obstet. Gynec., $69,962$.

—, Dampeer, T. K., and Dukes, C. D. (1957). Ibid., 73, 1080.

- and Dukes, C. D. (1959). Ann. N.Y. Acad. Sci., 83, 280.

Hayflick, L., and Chanock, R. M. (1965). Bact. Rev., 29, 185.

Heltai, A., and Taleghany, P. (1959). Amer. J. Obstet. Gynec., 77, 144.

Hughes, H. E., Gordon, A. M., and Barr, G. T. D. (1966). J. Obstet. Gynaec. Brit. Cwlth, in press.

Klieneberger-Nobel, E. (1950). Quart. J. micr. Sci., 91, 340.

- (1962). Pleuropneumonia-like Organisms (PPLO), Mycoplasmataceae. Academic Press, New York.

Nicol, C. S., and Edward, D. G. ff (1953). Brit. J. vener. Dis., 29, 141.

Preston, N. W., and Morrell, A. (1962). J. Path. Bact., 84, 241.

Randall, J. H., Stein, R. J., and Ayres, J. C. (1950). Amer. J. Obstet. Gynec., 59, 404.

Ray, J. L., and Maughan, G. M. (1956). West. J. Surg., 64, 581.

Robinson, S. C., and Mirchandani, G. (1965). Amer. J. Obstet. Gynec., 91, 1005.

Slingerland, D. W., and Morgan, H. R. (1952). J. Amer. med. Ass., $150,1309$.

Somerson, N. L., Rubin, A., Smith, P. F., and Morton, H. E. (1955) Amer. J. Obstet. Gynec., 69, 848.

Stokes, E. J. (1955). Lancet, 1, 276.

Zinnemann, K., and Turner, G. C. (1963). J. Path. Bact., 85, 213. 